\title{
Attitudes and acceptability of organ and tissue donation registration in the emergency department: a national survey of emergency physicians
}

\author{
Michael Hickey ${ }^{1,2,5}$ (D) Krishan Yadav ${ }^{1,2} \cdot$ Kasim E. Abdulaziz $^{2} \cdot$ Monica Taljaard $^{2} \cdot$ Carly Hickey $^{3} \cdot$ Michael Hartwick $^{2,4}$. \\ Aimee Sarti $^{2,4} \cdot$ Lauralyn Mclntyre ${ }^{2,4}$. Jeffrey J. Perry ${ }^{1,2}$
}

Received: 26 April 2021 / Accepted: 6 January 2022 / Published online: 6 February 2022

(c) The Author(s), under exclusive licence to Canadian Association of Emergency Physicians (CAEP)/ Association Canadienne de Médecine d'Urgence (ACMU) 2022

\begin{abstract}
Purpose There is a worldwide shortage of organs for transplantation. One method to increase the number of organs available for transplant is to increase the number of registered organ donors. The emergency department (ED) may be a suitable venue to disseminate knowledge to patients about organ donation, and to offer an immediate or future opportunity to register as an organ donor. This study aimed to assess emergency physicians' attitudes and acceptability of an ED-based organ donation registration initiative.

Methods We developed and distributed a national postal survey using a modified Dillman's tailored design technique to a random sample of emergency physicians selected from the Canadian Medical Directory.

Results From a total of 474 delivered surveys, we received 228 responses (48.1\%). 98.5\% of emergency physicians support the concept of deceased organ donation. $85.1 \%$ felt that the emergency department is an appropriate setting to disseminate information regarding organ donation and $77.6 \%$ felt that it is an appropriate location to offer an immediate opportunity to register as an organ donor. $74.1 \%$ of physicians who responded report to be personally registered as an organ donor.

Conclusion Most emergency physicians are supportive of organ donation promotion in the ED, including offering an immediate opportunity to register.
\end{abstract}

Keywords Emergency department · Organ donation

\section{Résumé}

Objectif Il y a une pénurie mondiale d'organes destinés à la transplantation. Une méthode pour augmenter le nombre d'organes disponibles pour la transplantation est d'augmenter le nombre de donneurs d'organes enregistrés. Le service des urgences (SU) peut être un lieu approprié pour informer les patients sur le don d'organes et leur offrir la possibilité, immédiate ou future, de s'inscrire comme donneur d'organes. Cette étude visait à évaluer les attitudes des médecins urgentistes et l'acceptabilité d'une initiative d'enregistrement des dons d'organes aux urgences.

Michael Hickey

michael.hickey@unityhealth.to

1 Department of Emergency Medicine, University of Ottawa, Ottawa, ON, Canada

2 Clinical Epidemiology Program, Ottawa Hospital Research Institute, Ottawa, ON, Canada

3 Queensway Carleton Hospital, Ottawa, ON, Canada

4 Division of Critical Care, Department of Medicine, University of Ottawa, Ottawa, ON, Canada

5 St. Joseph's Health Centre, 30 The Queensway, Toronto, ON M6R 1B5, Canada 
Méthodes Nous avons élaboré et distribué une enquête postale nationale en utilisant une technique modifiée de conception sur mesure de Dillman à un échantillon aléatoire de médecins urgentistes sélectionnés à partir de l'annuaire médical canadien. Résultats Sur un total de 474 questionnaires remis, nous avons reçu 228 réponses (48,1\%). 98,5\% des médecins urgentistes soutiennent le concept du don d'organes de personnes décédées. 85,1\% ont estimé que le service des urgences est un lieu approprié pour diffuser des informations sur le don d'organes et $77,6 \%$ ont estimé que c'est un lieu approprié pour offrir une possibilité immédiate de s'inscrire comme donneur d'organes. $74,1 \%$ des médecins qui ont répondu déclarent être personnellement inscrits comme donneurs d'organes.

Conclusion La plupart des médecins urgentistes sont favorables à la promotion du don d'organes dans les urgences, notamment en offrant la possibilité de s'inscrire immédiatement.

\section{Clinician's capsule}

\section{What is known about this topic?}

It is unknown if the emergency department (ED) is acceptable to promote organ donation registration.

What did this study ask?

Are emergency physicians open to, and supportive of promoting organ donation registration in the ED?

\section{What did this study find?}

Most emergency physicians are supportive of organ donation promotion in the ED, including offering an immediate opportunity to register.

Why does this study matter to clinicians?

Emergency physicians are supportive of organ donation and the majority are registered organ donors.

\section{Introduction}

Worldwide, the demand for organs for transplantation far exceeds the supply. As of December 31, 2019, there were 4352 Canadians on a waiting list for an organ transplant, and 249 died waiting [1]. Spreading awareness and increasing the number of citizens who are registered to donate their organs after death may prevent many of these deaths. In most Canadian provinces and territories, an "opt-in" system exists whereby citizens register their consent for organ donation after death via an electronic registry, managed by provincial organizations responsible for organ donation (for example, Trillium Gift of Life in Ontario). However, provincial organ donation organization personnel usually must obtain family consent prior to proceeding with organ donation, regardless of registration status. Family members' knowledge of prior registered consent is an important determinant in their authorization to proceed with organ donation after death [2, 3]. Therefore, creating improved opportunities for individuals to register as organ donors will result in an increased likelihood of both fulfilling their wish to donate, as well as helping people in need of an organ transplant. Since the beginning of the COVID-19 pandemic [4], the number of organ transplants has significantly declined [5]. Therefore, there is an increased need to highlight the importance of organ donation registration amongst the public.

In Canada, 96\% of individuals support organ donation [6] and most have the option to register with the renewal of their health card or driver's license [7]. However, some provinces have low rates of registration of eligible citizens, such as 35\% in Ontario [6]. Thus, additional means of registering organ donation consent are necessary to improve the registration rates of eligible donors. While organ donation registration interventions have been previously studied in some primary care settings with some success [8], it is possible that emergency department (ED) waiting areas can be utilized as an additional venue to spread awareness regarding deceased organ donation registration to patients and visitors who do not require immediate treatment. Some have advocated that the ED not only exist as a safety net for health but also as a means for important public health initiatives [9]. The ED is also a unique environment for this for several reasons. First, since ED patients have health on their mind, it may be an opportune time to raise awareness about the need for organ donors. Given that Canadian EDs see about 15 million visits per year [10], this could potentially lead to a substantial increase in the proportion of citizens who are registered organ donors. Secondly, there is very little literature to date examining the role of the ED pertaining to organ donation promotion, but some recent studies suggest an increasing interest in strengthening the relationship between emergency medicine and organ donation [11, 12]. In addition, a recent survey of Canadian ED patients suggests that they are accepting of the idea of organ donation registration in the ED, justifying the further study of this intervention [13].

Physicians are one group of key stakeholders in ED operations, and are the focus of the current study.

Our objectives were to assess emergency physicians' attitudes and acceptability of utilizing the ED to promote organ donation registration; examine the perceived facilitators and barriers related to this; and finally, to examine physicians' support for organ donation and compare this to the proportion who are themselves personally registered for donation. 


\section{Methods}

\section{Study design and participants}

This study was a postal survey of emergency physicians in Canada. To be eligible, physicians must have been actively practicing adult emergency medicine at the time of the survey. Using computer-generated random numbers, a random sample of 500 was selected from the 2995 emergency physicians listed in the 2019 Canadian Medical Directory (CMD). The CMD is a comprehensive database of physician information which is collected from medical schools and provincial and national organizations.

\section{Survey development}

This study was informed by Dillman's Tailored Design technique for survey development [14]. The questions were developed after 12 in-person, key-informant interviews with emergency and critical care nurses, physicians and researchers with extensive experience and knowledge in organ donation, and the entire development process was overseen by a survey research methodologist. We then performed cognitive interviews separately with a group of five staff emergency physicians and five emergency medicine residents to assess face validity and content. This was completed to identify any shortcomings with the language, grammar, or technical aspects, and to verify the face validity and sensibility of the questions. The survey was then translated into French. We then piloted the final draft of the survey with 10 English and 10 French randomly selected emergency physicians from our sample to identify any potential problems with the postal procedure or completion of the survey. No modifications were required following the pilot phase, and as such, the pilot survey responses were included in our sample. The final survey (see Appendix) consisted of a total of 24 questions divided into four sections: demographic and practicerelated information, attitudes regarding organ donation and personal organ donation registration status, acceptability of using the ED to promote organ donation and registration (including a question regarding modes of providing the public with information regarding registration), and related perceived facilitators and barriers. Most of the questions were designed using a five-point Likert scale for responses. This study was approved by the Ottawa Health Science Network Research Ethics Board.

\section{Survey administration}

The final survey was mailed to all English and French-speaking emergency physicians in our random sample. The sample size was based on a variance of 0.25 with $95 \%$ confidence and a margin of error of 0.07 . This resulted in 196 subjects.
Based on an expected response rate of 40-50\% from previous studies that surveyed the same population $[15,16]$, we chose to survey 500 physicians. Half of the participants were randomly selected to receive a prenotification letter approximately one week prior to the survey outlining that they had been selected to receive a survey to emphasize the importance of their input. One week later, the first package was sent to all 500 physicians and included a cover letter, survey, postage-paid return envelope and a \$3 Tim Horton's coffee gift card. Reminder letters, including another copy of the survey were sent to non-respondents approximately every three weeks. The final reminder was mailed using Xpresspost, using a larger envelope with greater visual appeal that is traceable and delivered nationally within two business days. The rationale for sending prenotification to only half of the sample was a sub-study developed a priori to test the effect of prenotification on the response rate which will be reported separately.

\section{Outcome measures}

The primary objective of the survey was to determine emergency physicians' attitude and acceptability of utilizing the ED to promote organ donation registration. Secondary objectives were to examine the physicians' general support towards organ donation and to compare this to the proportion of physicians who are personally registered organ donors.

\section{Data analysis}

Descriptive statistics were used to summarize physicians' responses. $\chi^{2}$ tests were conducted to compare characteristics of physicians based on personal organ donor registration status. An $\alpha$-level of 0.05 was set for two-sided significance tests. Data were analyzed using SAS version 9.2 (SAS Institute, Cary, NC, USA).

\section{Results}

\section{Respondents}

A total of 500 emergency physicians were contacted to participate in the study, and 26 surveys were undeliverable. Of 474 delivered surveys, 228 were returned, resulting in an overall response rate of $48.1 \% .27$ physicians who returned the survey were ineligible because they were no longer practicing emergency medicine. Therefore, 201 responses were included for final data analysis. Demographic information for the respondents is presented in Table 1. Ontario physicians comprised the majority of respondents (41.3\%), followed by Quebec (22.9\%) and British Columbia (17.4\%), which is consistent with the proportion of physicians in these 
provinces listed in the CMD. Most physicians were 10 or less years into practice (72.1\%) and had additional certification in emergency medicine (84.3\%).

\section{Attitudes and acceptability of ED organ donation registration}

Most respondents reported that they are personally registered as organ donors $(74.1 \%)$. The most common reasons for those who are not registered was due to not knowing how to register $(6.5 \%)$, "other" $(6.0 \%)$ or a personal preference to not donate their organs (4.0\%). Four of the eight who selected "other" specified that their spouse or family members are aware of their wishes and therefore they felt that formal registration is unnecessary. There was no association between registration status and geographic region of Canada, sex or practice setting.

As depicted in Table 2, a majority of emergency physician respondents either "strongly support" or "somewhat

Table 1 Distribution of respondent characteristics $(n=201)$

\begin{tabular}{lc}
\hline Characteristic & Respondents, $N(\%)$ \\
\hline Female & $75(37.3)$ \\
Mean age, years (SD) & $46(11.0)$ \\
Years in practice & \\
$<5$ & $71(35.3)$ \\
$5-10$ & $74(36.8)$ \\
$11-20$ & $39(19.4)$ \\
$>20$ & $17(8.5)$ \\
Practice setting & \\
Academic/Tertiary & $89(44.3)$ \\
Community (Teaching) & $81(40.3)$ \\
Other & $22(11.4)$ \\
Community (Non-teaching) & $9(4.0)$ \\
Professional designation & \\
CCFP (EM) & $110(54.7)$ \\
FRCPC & $68(33.8)$ \\
Other & $22(10.9)$ \\
CCFP & $1(0.5)$ \\
Average number of shifts worked per month & \\
6-12 & $105(52.2)$ \\
13-18 & $76(37.8)$ \\
Greater than 18 & $16(8.0)$ \\
Less than 6 & $1(0.5)$ \\
Unanswered & $3(1.5)$ \\
Holds formal organ donation organization & \\
affiliation & \\
Yes & $194(96.5)$ \\
No & \\
\hline - & \\
\hline
\end{tabular}

CCFP Canadian College of Family Physicians, CCFP (EM) CCFP; special competency in Emergency Medicine, FRCPC Fellow of the Royal College of Physicians of Canada support" the concept of deceased organ donation (a total of $98.5 \%$; Table 2). $85.1 \%$ of respondents either "strongly support" or "somewhat support" the concept of disseminating information about organ donation to patients in the ED waiting area, and $77.6 \%$ either "strongly support" or "somewhat support" the concept of offering ED patients and visitors an immediate opportunity to register while they await medical care. $62.7 \%$ of respondents felt that ED patients would be open to receiving information regarding organ donation in the ED. Similarly, $54.2 \%$ \% felt that ED patients would be open to being offered an immediate opportunity to register as an organ donor in the ED. $45.7 \%$ felt that ED patients would be open to receive instructions on how to register as an organ donor after their ED visit is completed.

\section{Comfort levels with active approach by provider type}

Respondents were asked to report their comfort level with various ED provider types should a face-to-face approach be undertaken in offering patients information regarding organ donation in the ED. A total of $84.6 \%$ of physicians were either "very comfortable" or "somewhat comfortable" with provincial organ donation organization staff providing information about donation to patients and about half of the respondents (50.3\%) were also either "very comfortable" or "somewhat comfortable" with ED nurses taking on this role. Many physicians were either "very uncomfortable" or "somewhat uncomfortable" with emergency physicians/ residents $(43.8 \%)$ or medical students $(56.2 \%)$, respectively.

\section{Respondents' support for information delivery methods regarding organ donation to ED patients}

A total of $82.1 \%$ of physicians felt that signage posted in ED waiting areas should be utilized and $66.2 \%$ reported that an electronic device (e.g. iPad) would be acceptable to provide organ donation information. Just $32.3 \%$ of all respondents felt that a face-to-face approach by personnel would be optimal.

\section{Perceived potential facilitators and barriers in the promotion of organ donation registration in the ED}

A majority of physician respondents felt that the societal/ public importance of increasing donation rates (91\%), willingness to help others (81.6\%), patient's previous awareness of donation $(81.1 \%)$ and having a strong institutional donation culture $(61.7 \%)$ were important facilitators to consider. Several potential barriers to the consideration of organ donation registration in ED waiting areas that were considered "very significant" or "somewhat significant" by physicians 
Table 2 Attitudes and acceptability of organ and tissue donation registration in the emergency department (\%,N=201)

\begin{tabular}{|c|c|c|c|c|c|}
\hline Question/statement & Strongly support & $\begin{array}{l}\text { Some- } \\
\text { what } \\
\text { support }\end{array}$ & Neutral & $\begin{array}{l}\text { Some- } \\
\text { what } \\
\text { oppose }\end{array}$ & $\begin{array}{l}\text { Strongly } \\
\text { oppose }\end{array}$ \\
\hline 1. In general, do you support the concept of deceased organ donation? & 89.5 & 9.0 & 1.0 & 0.5 & 0 \\
\hline $\begin{array}{l}\text { 2. Provincial organ donation organizations should attempt to increase the number of } \\
\text { registered organ donors }\end{array}$ & 85.6 & 9.5 & 4.4 & 0.5 & 0 \\
\hline $\begin{array}{l}\text { 3. The emergency department waiting area is an appropriate setting to disseminate } \\
\text { information regarding organ and tissue donation to capable patients who do not } \\
\text { need immediate attention and visitors }\end{array}$ & 46.8 & 38.3 & 4.0 & 6.0 & 0.5 \\
\hline $\begin{array}{l}\text { 4. The emergency department waiting area is an appropriate setting to offer patients } \\
\text { and visitors an immediate opportunity to register as an organ and tissue donor } \\
\text { while they await medical care }\end{array}$ & 39.8 & 37.8 & 11.9 & 6.5 & 4.0 \\
\hline $\begin{array}{l}\text { 5. Emergency department patients would be open to receiving information regarding } \\
\text { deceased organ donation in emergency department waiting areas }\end{array}$ & 18.4 & 44.3 & 25.9 & 9.5 & 2.0 \\
\hline $\begin{array}{l}\text { 6. Emergency department patients would be open to being offered an immediate } \\
\text { opportunity to register for deceased organ donation in emergency department } \\
\text { waiting areas }\end{array}$ & 17.4 & 36.8 & 32.8 & 9.5 & 3.5 \\
\hline $\begin{array}{l}\text { 7. Emergency department patients would be open to being offered instructions on } \\
\text { how to register as an organ donor in the future, following their emergency depart- } \\
\text { ment visit }\end{array}$ & 30.3 & 15.4 & 15.4 & 5.5 & 1.5 \\
\hline
\end{tabular}

Table 3 Perceived potential facilitators and barriers of organ donation registration in the ED $(\%, N=201)$

\begin{tabular}{|c|c|c|c|c|c|}
\hline & Very significant & $\begin{array}{l}\text { Somewhat } \\
\text { significant }\end{array}$ & Don't know & $\begin{array}{l}\text { Somewhat } \\
\text { insignificant }\end{array}$ & $\begin{array}{l}\text { Very } \\
\text { insignifi- } \\
\text { cant }\end{array}$ \\
\hline \multicolumn{6}{|l|}{ Facilitator } \\
\hline Strong Donation Culture at Institution & 37.8 & 23.9 & 20.4 & 2.5 & 4.0 \\
\hline Societal/Public Importance of Increasing Donation Rates & 51.2 & 39.8 & 4.0 & 1.0 & 2.0 \\
\hline Patient's Willingness to Help Others & 40.8 & 40.8 & 13.4 & 2.0 & 1.0 \\
\hline Patient's Previous Awareness of Donation & 21.4 & 59.7 & 13.4 & 1.5 & 1.5 \\
\hline \multicolumn{6}{|l|}{ Barrier } \\
\hline Ethical Barriers & 14.4 & 40.3 & 20.0 & 17.9 & 7.0 \\
\hline Religious Barriers & 16.9 & 36.8 & 20.9 & 17.4 & 8.0 \\
\hline Lack of Patient Interest & 16.9 & 41.3 & 17.9 & 20.4 & 3.0 \\
\hline Time Constraints & 48.2 & 38.3 & 4.0 & 6.5 & 3.0 \\
\hline Department Flow/Efficiency & 52.7 & 33.3 & 4.5 & 7.0 & 2.5 \\
\hline Availability of Staffing/Personnel & 56.2 & 32.3 & 64.7 & 4.0 & 1.0 \\
\hline Hospital Costs & 13.4 & 21.9 & 32.3 & 18.9 & 13.4 \\
\hline Patient Privacy & 10.4 & 40.3 & 20.4 & 15.4 & 5.5 \\
\hline Staff Skill/Confidence in Discussing Organ Donation & 18.4 & 40.3 & 20.4 & 15.4 & 5.5 \\
\hline
\end{tabular}

are listed in Table 3. The availability of appropriate personnel (88.4\%), time constraints (86.5\%) and a negative effect on ED efficiency (86.0\%) were reported most frequently.

\section{Discussion}

This study explores emergency physicians' attitudes and acceptability of utilizing the ED waiting area to offer patients and visitors information regarding organ donation registration and an opportunity to become registered organ donors. Most respondents support the concept of deceased organ donation and feel that organ donation organizations should attempt to increase the number of registered organ donors. In addition, we found that $65 \%$ of emergency physicians report being personally registered as organ donors, compared to $57.4 \%$ of emergency physicians in Ontario [17]. Most physicians generally support donation and the concept of registration in the ED. Several facilitators and barriers that could support this approach were identified. 
Many respondents were concerned that such an endeavor would threaten the efficiency of the ED and its providers, in addition to the consumption of a significant amount of time and human resources. This may also explain the reason why physicians were more accepting of organ donation organization staff and nurses performing the face-to-face approach, rather than physicians themselves. In addition, compared to posted signage and electronic device availability to facilitate the intervention, only $32.3 \%$ of respondents felt the face-toface approach is ideal. This could be further explored in a future study qualitatively, to better understand these results.

To our knowledge, there is little previously published work regarding organ donation registration in the ED. A recent survey of Canadian ED waiting room patients and visitors was conducted to examine the acceptability and feasibility of organ donation registration in the ED [13]. Participants were recruited to complete a self-administered, paper-based survey exploring their feelings regarding organ donation registration in the ED. $63.5 \%$ of participants reported that the ED was an acceptable place to provide donation information, and about a third stated they would themselves consider registering while in the ED. This finding is in keeping with what emergency physicians in the current study perceive about patients' open mindedness to the possibility of ED organ donation registration.

Strengths of this study include the use of robust methodology and a modified Dillman's Tailored Design technique for survey development and distribution [14]. It was conducted on a large random sample of emergency physicians across Canada and likely includes a true representation of practicing Canadian emergency physicians. Additionally, a response rate of greater than $45 \%$ is much higher than most emergency physician surveys, some of which have recently reported response rates less than $20 \%[18,19]$.

This study has some limitations. The possibility of non-response bias cannot be ruled out, based on the $48 \%$ response rate. Given that most respondents were registered organ donors, a bias may exist whereby those who are registered themselves may be more likely to respond to a survey regarding organ donation. The means by which physicians were identified for the study may have led to omitting general practitioners or family medicine specialists who also practice in the ED. We observed a higher proportion of respondents from Ontario, Quebec and British Columbia which is consistent with the proportion of those listed in the CMD. Interestingly, we found that the gender demographic of the respondents deviated from what we expected. We observed a higher proportion of female respondents (37.3\%) than expected based on national physician demographics, which report a lower proportion of females practicing emergency medicine in Canada (31.3\%) [20]. In keeping with this, Li et al. [17] reported a higher proportion of female to male physicians in Ontario, Canada who were registered as organ donors (50.0\% versus $39.1 \%)$. However, we did not observe this difference in registration between sexes amongst emergency physician respondents in the current study.

Considering the results of both this study and Ellis et al. [13], it seems that an ED-based registration strategy is acceptable to emergency physicians and can be further considered for pilot testing in some EDs.

If this organ donation registration intervention was implemented in Canadian EDs, it could potentially significantly increase the number of registered organ donors. Subsequently, this could translate into more patients receiving a lifesaving organ transplant.

\section{Conclusion}

Most emergency physicians are supportive of organ donation promotion in the ED, including offering an immediate opportunity to register.

Supplementary Information The online version contains supplementary material available at https://doi.org/10.1007/s43678-022-00262-8.

Funding This study was partially funded by a grant from the Department of Emergency Medicine, University of Ottawa.

\section{Declarations}

Conflict of interest Dr. Jeffrey Perry is supported by the Heart and Stroke Foundation of Ontario through a Mid-Career Award. Dr. Michael Hartwick receives a salary as Regional Medical Lead Donation from Trillium Gift of Life Network, Ontario's organ donation organization. Dr. Michael Hickey receives a salary as a Hospital Donation Physician from Trillium Gift of Life Network, Ontario's organ donation organization.

Ethical approval This study was approved by the Ottawa Health Sciences Network Research Ethics Board.

\section{References}

1. Canadian Institute for Health Information. Annual statistics on Organ Replacement in Canada: Dialysis, Transplantation and Donation, 2009 to 2018. Ottawa, ON; 2019.

2. Siminoff LA, Gordon N, Hewlett J, Arnold RM. Factors influencing families' consent for donation of solid organs for transplantation. JAMA. 2001;286(1):71-7.

3. Shah MB, Vilchez V, Goble A, Daily MF, Berger JC, Gedaly R, et al. Socioeconomic factors as predictors of organ donation. $\mathrm{J}$ Surg Res. 2018;221:88-94.

4. World Health Organization. WHO Director-General's opening remarks at the media briefing on COVID-19. 11 March 2020. 2020.

5. Owens B. Organ transplants drop dramatically during pandemic. CMAJ. 2020;192(25):E692-3. 
6. Trillium Gift of Life Networ. Registration Statistics 2019. Available at: https://beadonor.ca/scoreboard.

7. Rosenblum AM, Li AH, Roels L, Stewart B, Prakash V, Beitel J, et al. Worldwide variability in deceased organ donation registries. Transpl Int. 2012;25(8):801-11.

8. Jones CP, Papadopoulos C, Randhawa G. Primary care interventions to encourage organ donation registration: a systematic review. Transplant Rev (Orlando). 2017;31(4):268-75.

9. McKay MP, Vaca FE, Field C, Rhodes K. Public health in the emergency department: overcoming barriers to implementation and dissemination. Acad Emerg Med. 2009;16(11):1132-7.

10. Canadian Institute for Health Information.Number of ED visits by CTAS level, Participating Provinces and Territories, National Ambulatory Care Reporting System. 2020.

11. McCallum J, Ellis B, Dhanani S, Stiell IG. Solid organ donation from the emergency department-a systematic review. CJEM. 2019;21(5):626-37.

12. Healey A, Singh JM. Organ donation-emergency medicine's call to action. CJEM. 2019;21(5):569-71.

13. Ellis B, Hartwick M, Perry JJ. Register to donate while you wait: assessing public opinions of the acceptability of utilizing the emergency department waiting room for organ and tissue donor registration. CJEM. 2019;21(5):622-5.

14. Dillman DA. Mail and internet surveys: the tailored design method. 2nd ed. Hoboken: Wiley; 2007.

15. Perry JJ, Losier JH, Stiell IG, Sharma M, Abdulaziz K. National survey of emergency physicians for transient ischemic attack
(TIA) risk stratification consensus and appropriate treatment for a given level of risk. CJEM. 2016;18(1):10-8.

16. Abdulaziz K, Brehaut J, Taljaard M, Emond M, Sirois MJ, Lee JS, et al. National survey of physicians to determine the effect of unconditional incentives on response rates of physician postal surveys. BMJ Open. 2015;5(2): e007166.

17. Li AH, Dixon S, Prakash V, Kim SJ, Knoll GA, Lam NN, et al. Physician registration for deceased organ donation. JAMA. 2014;312(3):291-3.

18. Wright N, Lin Y, Cheng A. How is quality of cardiopulmonary resuscitation being assessed? A national survey of Canadian emergency medicine physicians. CJEM. 2019;21(6):744-8.

19. Staple L, MacIntyre J, Murphy NG, Beed S, LeBlanc C. Organ and tissue donation from poisoned patients in the emergency department: a Canadian emergency physician survey. CJEM. 2019;21(1):47-54.

20. Canadian Medical Association. Number and percent distribution of physicians by specialty and gender, Canada, 2019. Available at: https://www.cma.ca/sites/default/files/2019-11/2019-06-specsex_0.pdf

21. Abdulaziz K, Brehaut J, Taljaard M, Emond M, Sirois MJ, Lee JS, et al. National survey of emergency physicians to define functional decline in elderly patients with minor trauma. CJEM. 2015;17(6):639-47. 